\title{
The Judgment of the Italian Constitutional Court on State Immunity in Cases of Serious Violations of Human Rights or Humanitarian Law: a tentative analysis under international law*
}

\author{
O Julgamento da Corte Constitucional Italiana sobre Imunidade Estatal \\ em Casos de Sérias Violações de Direitos Humanos ou Direito Humanitário: \\ uma tentativa de análise sob o enfoque do Direito Internacional
}

\author{
Pasquale de Sena \\ Università Cattolica del Sacro Cuore, Milão - Itália
}

\begin{abstract}
The article discusses the judgment 238/2014 rendered by the Italian Constitutional Court on State immunity in cases of serious violations of human rights or humanitarian law. It aims to provide some critical reflections on the potential relevance of this judgment in the further development of the international legal regime in respect of state immunity in $j$ cases of serious violations of human rights or humanitarian law. To best address this purpose, the analysis will be divided into two parts. In the first part, it will be addressed the potential significance of the stance taken by the Court. In the second part, the Italian Constitutional Court's approach will be assessed, with a focus on its capacity to affect to a greater extent the development of the relevant practice.
\end{abstract}

Keywords: State Immunity. Italian Constitutional Court. Human Rights. Humanitarian Law.
Resumo: $\mathrm{O}$ artigo discute o julgamento 238/2014 emanado pela Corte Constitucional Italiana sobre Imunidade Estatal em casos de sérias violações a direitos humanos ou direito humanitário. O propósito é oferecer algumas reflexões críticas sobre a potencial relevância deste julgamente no posterior desenvolvimento do regime jurídico internacional em relação a imunidades estatais em casos de sérias violações a direitos humanos ou direito humanitário. Para melhor abordar esta questão, a análise será dividida em duas partes. Na primeira parte, será abordado o potencial significado do argumento adotado pela Corte. Na segunda parte, a abordagem da Corte Constitucional Italiana será avaliada, com foco na sua capacidade de afetar em uma maior dimensão o desenvolvimento da prática relevante.

Palavras-chave: Imunidade Estatal. Corte Constitucional Italiana. Direitos Humanos. Direito Humanitário.

Recebido em: 04/08/2016

Revisado em: 28/09/2016

Aprovado em: 09/10/2016 


\section{Introduction}

The judgment 238/2014, rendered by the Italian Constitutional Court has already been discussed by a number of Italian scholars. Differing opinions have been delivered on important aspects covered by this judgment ${ }^{1}$, particularly on the legal consequences of a conflict between general international law and on the fundamental values of the Italian legal order $^{2}$. Little attention, by contrast, has been paid to the potential relevance of this judgment in the further development of the international legal regime in respect of state immunity in cases of serious violations of human rights or humanitarian law.

It is for this reason that this paper aims to provide some critical reflections on the issue. To best address this purpose, this analysis

${ }^{1}$ F Fontanelli, 'I Know It's Wrong but I Just Can't Do Right. First Impressions on Judgment no 238 of 2014 of the Italian Constitutional Court' (2014) Diritti comparati $<$ www.diritticomparati.it/2014/10/i-know-its-wrong-but-i-just-cant-do-right-firstimpressions-on-judgment-no-238-of-2014-of-the-italian-constitutional.html>; L Gradoni, 'Corte Costituzionale italiana e Corte internazionale di giustizia in rotta di collisione sull'immunità dello Stato straniero dalla giurisdizione civile' (2014) SIDIBlog, <www. sidi-isil.org/sidiblog/ ?p=1101>; P De Sena, 'Spunti di riflessione sulla sentenza 238/2014 della Corte costituzionale (2014) ibid, $<$ www.sidi-isil.org/sidiblog/?p=1108>.

${ }^{2}$ According to the Constitutional Court, the traditional rule on state immunity for war crimes and crimes against humanity is without legal effect in the Italian legal order, since art 10, para 1, of the Italian Constitution (by virtue of which 'The Italian legal system conforms to generally recognized rules of international law') cannot be construed as allowing customary rules conflicting with fundamental legal values to be applied by Italian courts (see the English translation of the judgment provided by the Italian Constitutional Court, <www.cortecostituzionale.it/documenti/download/doc/recent_judgments/ S238_2013_en.pdf>, as well as the summary of the judgment, provided by F Messineo, Questions of International Law (2014) <www.qil-qdi.org/?p=856>). On this aspect, see L Gradoni, 'Giudizi costituzionali del quinto tipo. Ancora sulla storica sentenza della Corte costituzionale italiana' (2014) SIDIBlog, <www.sidi-isil.org/sidiblog/?p=1135>, P De Sena, 'Norme internazionali generali e principi costituzionali fondamentali, fra giudice costituzionale e giudice comune (ancora sulla sentenza 238/2014)' (2014) ibid, $<$ www.sidi-isil.org/sidiblog/?p=1186>, and A Ruggeri, 'La Corte aziona l'arma dei "controlimiti" e, facendo un uso alquanto singolare delle categorie processuali, sbarra le porte all'ingresso in ambito interno di norma internazionale consuetudinaria' (2014) Consulta Online, <www.giurcost.org/studi/index.html >. 
will be divided into two parts.In the first part, I will address the potential significance of the stance taken by the Court, with specific regard to the perspective that other domestic judgments may follow on the topic. More precisely, the Court's reasoning will be examined, with a view to verifying whether it might provide useful arguments for resetting the relationship between the international protection of human rights and the law of state immunity (paras 2 and 3). In the second part, the Italian Constitutional Court's approach will be assessed, with a focus on its capacity to affect to a greater extent the development of the relevant practice. The potential relevance of the court's approach, in identifying a general principle on the topic of individual access to justice, will therefore be briefly examined, as well as its role in the formation of a customary exception to the traditional regime on state immunity in cases of serious violations of human rights or humanitarian law (para 4). Some space will be also be devoted to reflecting on the possible consequences of the Solange perspective drawn by the Court on future judgments of the ICJ (ibid), as well as to the potential relevance under international law of the recourse had by the Court itself on the constitutional principles concerning access to justice.

\section{The Legal Arguments Used by the Court}

What are the legal arguments on the basis of which the Constitutional Court has decided that the customary regime on State immunity has no legal effect on the Italian legal system, in cases of international individual crimes? As stated by the Court, both Article 2 of the Constitution - which provides a solemn recognition of the fundamental ('inviolable') rights pertaining to every human person - and Article 24 - which provides the right to judicial protection - would be unlawfully sacrificed in such cases $^{3}$. More specifically, the sacrifice of the rights at stake, as a result of the imposition of the customary rule on the immunity of foreign States

\footnotetext{
${ }^{3}$ In the judgment, arts 2 and 24 are seen as being strictly intertwined, and art 24 itself * [...] is defined as 'a safeguard of human dignity as well, as it protects the right of access to justice for individuals in order to invoke their inviolable right[s]'; immediately after this sentence, it is stated that 'It would indeed be difficult to identify how much is left
} 
(as defined in its scope by the ICJ), is deemed 'untenable', insofar as it implies that the jurisdiction of domestic courts over claims for damages caused by serious international crimes cannot be exercised ${ }^{4}$. Provided that the 'rationale' for the said rule is the desire to avoid interference with the exercise of sovereign powers by a foreign State, such a need does not appear to be relevant in cases involving the commission of war crimes or crimes against humanity. In other words, in the Court's opinion, State actions that amount to grave breaches of fundamental human rights are to be excluded, as such, from the lawful exercise of governmental powers ${ }^{5}$. Hence, the above mentioned conclusion, according to which the sacrifice of articles 2 and 24 of the Constitution would be untenable in similar cases, under the Italian Constitution itself.

So it clearly emerges that the 'noyau dur' or core of the Court's reasoning on state immunity is based on assumptions that appear from the point of view of international law to be both axiological and logical, at the same time. There is no doubt, in fact, that the 'untenability' of the sacrifice of the right to judicial protection stems from the gravity of the war crimes committed by the German troops; i.e., from an axiological consideration. There is equally no doubt that the argument pursuant to which state immunity does not extend to unlawful State conduct is a logical one, insofar as these types of conduct are considered as not being covered by such a regime as a logical consequence ${ }^{6}$ of their unlawfulness under international law.

of a right if it cannot be invoked before a judge in order to obtain effective protection' (Judgment no 238 (n 2) para 3.4).

${ }^{4}$ ibid.

${ }^{5}$ In fact, in the Court's opinion, immunity is not intended to cover 'behaviors that do not represent the typical exercise of governmental powers, but are explicitly considered and qualified unlawful, since they are in breach of inviolable rights, as was recognized, in the present case, by the ICJ itself, and - before that Court - by the FRG [...]' (ibid).

6 'Immunity from jurisdiction of other States can be considered tenable from a legal standpoint, and even more so from a logical standpoint, and thus can justify on the constitutional plane the sacrifice of the principle of judicial protection of inviolable rights guaranteed by the Constitution, only when it is connected - substantially and not just formally - to the sovereign functions of the foreign State, i.e. with the exercise of its governmental powers' (ibid; italics added). 
Indeed, these assumptions are not completely novel in the general framework of both the case law and the debate concerning the relationship between State immunity and serious human rights violations ${ }^{7}$. As far as the first assumption is concerned, one may recall the judgment rendered by the District Court for the District of Columbia in 1992 in the Princz case $^{8}$, as well as the judgment of the Supreme Court of Greece in the Prefecture of Voiotia ${ }^{9}$ case. In both these judgments, room is left albeit in different ways - to the idea that state immunity cannot cover state actions that amount to grave breaches of international law rules ${ }^{10}$, particularly of jus cogens rules ${ }^{11}$. An analogous thesis is advanced also by some international law scholars, such as Reimann ${ }^{12}$ and Kokott ${ }^{13}$, who both assert that when committing serious international law violations,

${ }^{7}$ For an excellent, still valid, critical survey of the scientific debate, see F De Vittor, 'Immunità degli Stati dalla giurisdizione e tutela dei diritti umani fondamentali' (2002), 85 Rivista di diritto internazionale $573 \mathrm{ff}$; for a more up to date survey of the relevant case law, see R Van Alebeek, The Immunities of States and their Officials in International Criminal Law and International Human Rights Law(OUP 2008), esp ch 6.

${ }^{8}$ Princz v Federal Republic of Germany (23 december 1992) 813 F. Supp., $22 \mathrm{ff}$.

${ }^{9}$ Prefecture of Voiotia v Federal Republic of Germany (4 may 2000): see M Gavouneli, I Bantekas, 'Prefecture of Voiotia v. Federal Republic of Germany. Case No. 11/2000' (1995) 95 AJIL 198 ff.

${ }^{10}$ In the District Court's opinion, the FSIA 'has no role to play where the claims alleged involve undisputed acts of barbarism committed by a one-time outlaw nation which demonstrated callous disrespect for the humanity of an American citizen, simply because he was Jewish' (n 8, 26).

${ }^{11}$ In Prefecture of Voiotia, the Supreme Court of Greece rejected the jure imperi/jure gestionis distinction, by referring to the peremptory nature of the prohibition of the crimes at stake, on the basis of which Germany was considered as having tacitly waived its immunity (provided for by art 46 of the Hague IV Convention; M Gavouneli, I Bantekas (n 9) 202).

${ }^{12}$ M Reimann 'A Human Rights Exception to Sovereign Immunity: Some Thoughts on Princz V. Federal Republic of Germany' (1995) 16 Michigan J Intl L, 403 ff.

${ }^{13} \mathrm{~J}$ Kokott, 'Mißbrauch und Verwirkung von Souveränitätsrechten bei gravierenden Völkerrechtsvertößen', in U Beyerlin (ed), Recht zwischen Umbruch und Bewahrung, Festschrift für Rudolf Bernhardt (1995) 135 ff. 
States are not entitled to invoke immunity from jurisdiction, since they lose their immunity as a consequence of the gravity of these violations ${ }^{14}$.

Even the logical assumption which forms the backdrop of the judgment of the (Italian) Constitutional Court can be found in certain domestic judgments and in some scholarly contributions. It is easy to observe, for example, that the argument according to which state immunity does not extend to unlawful State conducts was used by the District Court for the District of Columbia in the Letelier case ${ }^{15}$ (in order to deny immunity to Chile, with regard to a political assassination occurring within the territory of the United States), as well as by the Court of Appeals for the Ninth Circuit in the Liu Case ${ }^{16}$ (in order to deny immunity to China, once again with regard to a political assassination occurring in the United States). Such a tendency is not surprising; if one considers that a similar way of thinking has been prevalent among international law scholars, since the 1940's. Suffice it to say, on one side, that a logical incompatibility between state immunity and unlawful state actions was assumed by R. Quadri, in 1941, in his seminal book on the immunity of foreign States ${ }^{17}$, even before the well known study of $\mathrm{H}$. Lauterpacht ${ }^{18}$; and suffice it to add, on the other, that many studies of $\mathrm{A}$. Bianchi were inspired by the need to get over such an incompatibility ${ }^{19}$.

\footnotetext{
${ }^{14}$ According M. Reimann such a loss would be the consequence of the non applicability in these cases of the principle of non interference in the internal affairs of States (n 12, 422-423), whereas J. Kokott refers to the doctrine of abuse of rights (n 12, 148 -149).

${ }^{15}$ Letelier v. Chile, 11 march 1980, 63 Int. Law Rep., 378 ff, 387.

${ }^{16}$ Liu v. Republic of China, 29 december 1989, 101 Int. Law Rep., 519 ff, 526.

${ }^{17}$ R. Quadri, La giurisdizione sugli Stati stranieri, (1941 CEDAM), 127.

${ }^{18}$ H. Lauterpacht, 'The Problem of Jurisdictional Immunities of Foreign States' (1951), 28 Brit. Y.B. Int'l L. 220 ff, 227.

${ }^{19}$ Among which, see, for ex., 'Serious Violation of Human Rights and Foreign States' Accountability Before Municipal Courts', in L.C. Vohrah et al. (Eds), Man's Inhumanity to Man. Essays on International Law in Honour of Antonio Cassese (KLUWER, 2003), $149 \mathrm{ff}$, as well as 'Denying State Immunity to Violators of Human Rights' (1993-1994), 46 Austrian JPub IntlL, 195 ff.
} 


\section{And Their Suitability for Application in Future Domestic Judgments}

May we conclude that after the judgment of the ICJ on the jurisdictional immunities of the State the logical and axiological arguments of the Italian Constitutional Court can effectively represent useful tools, in futures domestic judgments, for a possible reappraisal of the relationship between human rights and the law of state immunity under international law? In order (to try) to give an answer to this question, two remarks need to be briefly developed.First, it is to be recalled that in the aforementioned judgment, the ICJ excluded that under current customary law, States can be considered as being 'deprived' of immunity when they are accused of 'serious violations of international human rights law or the international law of armed conflict' ${ }^{20}$. Such a negative conclusion appears to be quite reasonable, at least if one examines the relevant practice from the point of view of the formation process of a specific customary exception to the traditional rule on state immunity ${ }^{21}$.

The second remark is strictly connected to the first one. If it is true, on the one side, that customary law has not developed to the above mentioned point, it is also true, on the other, that both the traditional rule on State immunity and the legal regime for serious violations of human rights and humanitarian law can be deemed expressions of two conflicting, fundamental principles of current international law: i.e., the sovereign equality of states and the protection of inviolable human rights. Whatever opinion one may have about the stance taken by the Court, in the same judgment, on the relationship between jus cogens and State immunity $^{22}$, the above circumstance does not require, evidently, any special demonstration.

\footnotetext{
${ }^{20}$ Jurisdictional Immunities of the State (Germany/Italy, Greece Intervening) (Judgment 3 February 2012) [2012] ICJ Rep 99, para 91.

21 ibid paras 81-91.

22 Ibid paras 92-97; for a (strongly) critical assessment, see R Pisillo Mazzeschi, 'Il rapporto fra norme di ius cogens e la regola sull'immunità degli Stati: alcune osservazioni critiche sulla sentenza della Corte internazionale di giustizia del 3 febbraio 2012' (2012) 6 Diritti umani e diritto internazionale $310 \mathrm{ff}$.
} 
That being said, both the preceding remarks ultimately mean that the logical and axiological arguments invoked by the (Italian) Constitutional Court are far from useful, when it comes to future domestic judgments concerning the relationship between human rights and the law of state immunity.

In this regard, it can first of all be contended that these arguments are rather simplistic, if compared to the in-depth investigation carried out by the ICJ in order to state that an human rights exception to the customary regime on state immunity has not yet come to light. One could reply that such a different approach appears to be justified, at least insofar as the Constitutional Court decided to confine itself to merely assessing the constitutionality of the customary regime on state immunity, without questioning the assessment of such a regime, in contrast to the assessment made by the ICJ under international law ${ }^{23}$. Apart from any consideration on this specific stance ${ }^{24}$, the fact remains, however, that under international law the arguments used by the Court do not go far enough, in the face of the opposite conclusion reached by the ICJ, on the basis of a careful analysis of the relevant state practice. Furthermore, it can be added that by simply invoking the gravity of the crimes at stake and the logical incompatibility between state immunity and unlawful state actions (such as the grave breaches of human rights and humanitarian law at stake), the Constitutional Court has ended up neglecting what has just been emphasized; namely, that both state immunity and the legal regime for serious violations of human rights or humanitarian law can be considered as being expressions of two conflicting general principles of international law, such as the sovereign equality of states and the protection of inviolable human rights. In

\footnotetext{
${ }^{23}$ According to the Court: 'International custom is external to the Italian legal order, and its application by the government and/or the judge, as a result of the referral of Article 10, para. 1 of the Constitution, must respect the principle of conformity, i.e. must follow the interpretation given in its original legal order, that is the international legal order. In this case, the relevant norm has been interpreted by the ICJ, precisely with a view to defining the dispute between Germany and Italy on the jurisdiction of the Italian judge over acts attributable to the Federal Republic of Germany (FRG)': Judgment no 238/2014 (n 2) para 3.1 .
}

${ }^{24}$ On this aspect, see below para 4. 
contrast, this circumstance appears to be of the utmost importance, if one takes into account that a specific customary rule, concerning the applicability of the law on state immunity in cases of serious violations of human rights cannot yet be proved. In the absence of such a rule, it emerges quite clearly that appropriate solutions to similar cases cannot be reached except by resorting to the aforementioned principles and balancing them on a case-by case basis. ${ }^{25}$ The recourse to such general principles was perceived - in contrast with the Constitutional Court - as being necessary by the Italian Supreme Court in the Ferrini judgment, ${ }^{26}$ as well as by the Greek and the Polish Supreme Courts, in the Margellos ${ }^{27}$ and the Natonievsky ${ }^{28}$ judgments.

As to the Ferrini case, it is worth recalling that the conclusion reached by the Court ${ }^{29}$ was based upon asystematic interpretation of the international legal order, which led to a consideration of the customary rule on State immunity and the legal regime for serious violations of human rights (and humanitarian law), as being expressions, respectively, of the two above-mentioned fundamental principles: the sovereign equality of states and the protection of fundamental rights ${ }^{30}$. A similar

${ }^{25}$ On this aspect, see the insightful comments on the ICJ judgment, made by L Gradoni, A Tanzi, 'Immunità dello stato e crimini internazionali tra consuetudine e bilanciamento: note critiche a margine della sentenza della Corte internazionale di giustizia del 3 febbraio 2012' (2012) 59 La Comunità internazionale 203 ff; in the same line of thought: P De Sena, F De Vittor, 'State Immunity and Human Rights: The Italian Supreme Court Decision on the Ferrini Case' (2005) 16 Eur J Intl L 89 ff.

${ }^{26}$ For a summary as well as a critical examination of this judgment, see P De Sena, F De Vittor (n 25).

${ }^{27}$ Margellos and others v. Federal Republic of Germany (17 September 2002) 129 ILR $533 \mathrm{ff}$.

${ }^{28}$ Natonievsky v. the Federal Republic of Germany and the Federal Chancellery for Payment (29 october 2010) 30 Polish YB Intl L 299 ff (summary).

${ }^{29}$ Germany was deemed to be not entitled to sovereign immunity for serious violations of human rights committed by German occupying forces in 1944.

${ }^{30}$ More precisely, the jurisdiction of the Italian courts over Germany was justified neither on account of the actual content of the allegedly violated human rights and humanitarian norms, nor as the mere consequence of their formal rank (i.e., their peremptorycharacter), but as result of the substantial importance that can be given to the value of human rights protection these norms are based on (P De Sena, F De Vittor (n 25) 110). 
stance can also be found in Margellos and Natonievsky, despite the fact that in both these judgments - in contrast with Ferrini and Prefecture of Voiotia ${ }^{31}$ - Germany was deemed entitled to sovereign immunity for the violations at stake. As it has been rightly argued ${ }^{32}$, this finding was reached by both the Polish and the Greek Supreme Court, on the basis of the idea whereby 'it cannot be said that State immunity imposes a disproportionate restriction on the right of access to courts, when the applicants have available to them reasonable alternative means to protect effectively their rights' ${ }^{33}$. This means that the above judgments can ultimately be regarded as the outcome of a balancing of the principle of effective judicial protection of international fundamental rights with that of state immunity, as it stems from the sovereign equality of States. Furthermore, the importance attributed, in Margellos, as well as in Natonievsky, to the availability of alternative means of restoration entails that both these rulings can be traced back to the widely known logic of the 'equivalent protection', so as this logic has been elaborated by the ECtHR (albeit) with specific reference to the immunity of international organizations.

\section{The Judgment of the Constitutional Court and the Future De- velopment of the Relationship Between State Immunity and Human Rights: some general reflections}

In the light of the foregoing it can be restated that the line of reasoning chosen by the Constitutional Court does not seem to be able to provide sound arguments for innovative future judgments, if compared to the 'balancing of principles' approach, chosen by some domestic courts with regard to the relationship between state immunity and human rights under international law.

\footnotetext{
${ }^{31}$ See above (n 9).

${ }^{32}$ L Gradoni, A Tanzi (n 25) 216, 217.

${ }^{33}$ Natoniewsky (n 28) 303; in a similar manner, in Margellos, the Greek (Special) Supreme Court took the time to conclude that alternative means of restoration had been provided for by German law in favor of the plaintiffs (n 27, 532).
} 
But may we infer from this that the judgment is definitively, manifestly unhelpful, when it comes to any future developments of this relationship?

My impression is that such a conclusion would go too far, if one considers that the present judgment is in contrast with the prevailing tendency which is to deny that the traditional rule on State immunity can be disregarded in cases involving serious violations of human rights or humanitarian $\operatorname{law}^{34}$. In spite of the choice of the Italian Constitutional Court not to deal autonomously with the identification of the general rules relevant to this case, it seems to me that the stance taken by the Court could gain considerable ground under international law, at least from two points of view.

Firstly, there is no doubt that the weight attributed to the right of access to justice is able to strengthen the idea that such a right is now a general principle of international law $^{35}$; i.e., a principle to be balanced with the general regime on state immunity, on a case-by-case basis ${ }^{36}$. Although the Court has neither resorted to international law principles, nor balanced them for the purpose of solving the case under examination, one cannot rule out that this judgment may be used precisely for that purpose $^{37}$, being that it is widely accepted that domestic judgments are to be referred to, as much for identifying customary rules as for identifying general principles of law $^{38}$.

${ }^{34}$ Suffice it to recall here that the ICJ Judgment was preceded by Al Adsani and has been followed by Jones.

${ }^{35}$ On this category, see G Gaja, 'General Principles of Law', in R Wolfrum (ed), Max Planck Encyclopedia of Public International Law (2012), (online edn, OUP), paras 7-32; with specific regard to the right of access to justice, see F Francioni, 'The Right of Access to Justice under Customary International Law' in F Francioni (ed), Access to Justice as an Human Right (2007 OUP) $11 \mathrm{ff}$.

${ }^{36}$ See above, para. 3 .

${ }^{37}$ This is all the more important, in light of the convergent tendency shown by both the CJEU and the ECtHR, respectively, in Kadi IIand Al Dulimi (see below).

${ }^{38}$ On the importance of the domestic case law in order to identify general principles of law recognized by civilized nations, see B Conforti, A Labella, An Introduction to International Law (Brill 2012) 39 ff; in more general terms: A Pellet, 'Article 38', in 
Moreover, nothing excludes the fact that the ruling of the Constitutional Court could represent a significant judicial precedent in the framework of the (possible) formation process of a customary exception to the traditional rule on State immunity in case of serious violations of human rights or humanitarian law. If it is true, on one side, that the Court recognizes that 'the interpretation by the ICJ of the customary law of immunity of States from the civil jurisdiction of other States for acts considered jure imperii is particularly qualified and does not allow further examination by national governments and/or judicial authorities, including this Court' ${ }^{39}$, it is to be pointed out, on the other, that the Court both recalls the decisive support given by the Italian case law to the restrictive doctrine of state immunity ${ }^{40}$, and advances the idea that its judgment 'may also contribute to a desirable - and desired by many evolution of international law itself' 41 . Not only does this mean that the Court is well aware that it is infringing the current customary regime on State immunity, but also that it hopes to be able to promote a change of this regime, insofar as such a change is clearly perceived - by the Court itself - as being imposed by a sort of widespread opinio necessitatis. On the other hand, the importance of the decision under examination in the process of formation of a new customary rule on State immunity cannot be challenged by contending that the stance taken by the Court is discordant with that adopted by the Italian Government and the Italian Parliament following the ICJ judgment ${ }^{42}$. Suffice it to stress, in this respect, that the Constitutional Court (as the 'guardian of the Constitution') has the last word within the Italian legal system; its stance can be therefore

A Zimmermann et al. (eds), The Statute of the International Court of Justice: A Commentary, (2nd edn, 2012 OUP) $731 \mathrm{ff}$.

${ }^{39}$ Judgment no 238/2014 (n 2) para 3.1 (italics added).

40 ibid, para 3.3 .

41 ibid.

${ }^{42}$ It is worth pointing out that a specific provision aimed at implementing that judgment had been adopted by the Italian Parliament: art 3 of Law 5/2013 (14 January 2013). By means of this provision, Italian courts were required to decline jurisdiction in conformity with the ICJ ruling, as well as to revoke any ruling previously adopted that conflicted with the ICJ Judgment, if so requested by the parties; such a provision has been declared constitutionally unlawful by the Court: Judgment no 238/2014 (n 2) para 5.1. 
legitimately deemed to be the current, official Italian position concerning the legal regime of state immunity ${ }^{43}$ in cases of serious violations of human rights or humanitarian law.

That being said, one may still wonder if the stance taken by the Court is to be deemed a significant one, so to say, even from a 'Solange' perspective. This question may be legitimately posed, provided that the Court itself has referred to the Kadi judgment, in order to strengthen the idea whereby the principle of effective judicial protection for individual rights is a fundamental, non-derogable principle, as much in the Italian legal order as in the EU legal order ${ }^{44}$. More precisely, one may wonder if such a stance is actually able to change the strict attitude adopted by the ICJ in its judgment.

A similar hypothesis is to be probably excluded with specific regard to the dispute between Germany and Italy. Should this dispute be brought again before the $\mathrm{ICJ}^{45}$, the Court would hardly be able to

${ }^{43}$ At least, as far as immunity from jurisdiction is concerned, given that a specific provision concerning immunity from execution has just been adopted by the Italian Parliament (n 44).

44 Judgment no 238/2014 (n 2) para 3.4.

${ }^{45}$ Against the Italian failure to comply with the ICJ judgment, Germany may have, first of all, recourse to the Security Council (art 94, para 2, of the UN Charter), as well as to the Committee of Minister of the Council of Europe, by virtue of the European Convention for the Peaceful Settlement of Disputes of 29 Avril 1957 (art 39, para 2), on the basis of which (art 1) the ICJ rendered its judgment; but neither this circumstance, nor the lack of significant judicial precedents seem to be able to exclude, at least in principle, that Germany may also have recourse to the Court, provided that: a) proceedings against Colombia have been recently instituted by Nicaragua at the ICJ, precisely with regard, inter alia, to the alleged violation of obligations stemming from a preceding ICJ judgment between the same parties (19 November 2012); b) the request for interpretation of the judgment Avena and Others Mexican Nationals (Mexico/United States) was actually aimed at achieving compliance with this judgment. In spite of this, it is quite likely that neither the first scenario nor the second one will take place for the time being, given that a new legislative provision has just been adopted (art 19 bis, Law 10 November 2014, n 162: 'Conversione in legge, con modificazioni, del decreto-legge 12 settembre 2014, n 132, recante misure urgenti di degiurisdizionalizzazione ed altri interventi per la definizione dell'arretrato in materia di processo civile'), by virtue of which bank and postal accounts of foreign states assigned to tasks which are part of their duty as public authorities are exempt from execution. 
modify its attitude, if one considers that not only would such a change amount to going against its preceding judgment ${ }^{46}$, but it would also entail the adoption of a completely different approach, such as the equivalent protection doctrine ${ }^{47}$. In spite of this, it should not be ruled out that the 'Solange' perspective, drawn by the Italian Constitutional Court, may affect the future ICJ case law with respect to the applicability of the customary law on state immunity in case of serious violations of human rights or humanitarian law. By taking into consideration the principle of effective judicial protection in the framework of the aforementioned doctrine, the Court could in fact minimize the risk that judgments to be adopted in similar cases may not be complied with by States involved in such judgments, by invoking precisely the need for respect of the principle at stake, as provided for by (their) domestic constitutional provisions $^{48}$.

To conclude, some brief remarks are to be developed with regard to the recourse had by the Constitutional Court to fundamental constitutional principles, in order to state the non-applicability (in the Italian legal system) of the customary regime on State immunity in case of international individual crimes. Such a recourse has been widely debated from the point of view of the Italian legal order ${ }^{49}$, whereas little or no attention has been paid to its potential relevance under international

\footnotetext{
${ }^{46}$ Should the principle of effective judicial protection for individual rights be taken into account, the ICJ would be led to verify the availability of alternative judicial means, in assessing effective respect for this principle (in the face of the customary regime on state immunity); provided that these means are not available within the German legal order, the Court would therefore be forced to reach an opposite conclusion with respect to that adopted in his first judgment.

${ }^{47}$ Taking into account both the above principle and the availability of alternative means for effective compliance with the former would clearly amount to choosing a completely different line of reasoning from that followed in the first judgment, insofar as such reasoning would appear to be based on the equivalent protection doctrine (Solange), rather than the simple identification of the relevant customary regime.

${ }^{48}$ It is unhelpful to say that this risk may increase in the event that other Supreme Courts be minded to follow the stance taken by the Italian Constitutional Court (maybe by means of different arguments: see above, para 3).

${ }^{49}$ See above (n 1).
} 
law. This seems quite understandable, provided that according to a well-established principle of international law, a State may not invoke provisions of its internal law as an excuse for failure to perform its obligations under international $\mathrm{law}^{50}$, including those relating to the cessation of an internationally wrongful act and the reparation for its consequences $^{51}$.

Nevertheless, it should be borne in mind that the right invoked by the Constitutional Court, i.e., the right of access to justice (in connection with the protection of human dignity), is also deemed to be a nonderogable right, in the context of the relevant international practice ${ }^{52}$. Furthermore, it is to be pointed out that both the ECJ in Kadi $\mathrm{II}^{53}$ and the ECtHR in Al Dulimi ${ }^{54}$ have recently invoked the need for respect of this right - albeit in the framework of the equivalent protection doctrine - in order to state that a full judicial review over SC decisions concerning

${ }^{50}$ See art 27 of the Vienna Convention on the Law of Treaties, as well as art 3 of the Draft Articles on Responsibility of States for Internationally Wrongful Acts and the commentary provided for by the ILC to this provision (Report of the International Law Commission on the Work of its 53rd Session, 23 April 1 June and 2 July-10 August 2001, $73 \mathrm{ff}$; esp 75-77, paras 2-6, for the relevant practice).

${ }^{51}$ See art 32 of the abovementioned Draft Articles, as well as the corresponding commentary (ibid 231-233).

${ }^{52}$ It is worth noting that both the UN Human Rights Committee and the ECtHR - like the Italian Constitutional Court (see above, para 2 and 3) - have considered the right to judicial protection as being basically a non-derogable right, although such a right is not explicitly included among the non-derogable ones, provided for by the Covenant and the European Convention (art 27, para 2, of the American Convention expressly provides, in turn, 'for judicial guarantees essential for the protection' of non-derogable rights): suffice it to say that in the General Comment No 29 on States of Emergency (UN doc CCPR/C/21/Rev.1/Add.11, 31 August 2001) it is vigorously emphasized that respect for the 'noyau dur' of the right to effective remedies must be safeguarded, also in states of emergency (para 14); in Brannigan and Mcbride v United Kingdom, App no 14553/89 and 14554/89 (ECtHR, Judgment 26 May 1993) an analogous conclusion is reached with specific regard to the right of habeas corpus, provided for by art 5 of the Convention (paras 63-66).

${ }_{53}$ Joined cases C-584/10 P, C-593/10 P and C-595/10 P, European Commission and Council of the European Union v Yassin Abdullah Kadi (CJEU Judgment 18 July 2013). ${ }^{54}$ Al-Dulimi and Montana Management Inc v Switzerland, App no 5809/08 (ECtHR Judgment 26 November 2013). 
targeted sanctions is perfectly lawful under the EU legal order, as well as in the legal systems of the contracting States of the European Convention, to the extent that the guarantees of an effective judicial protection are not provided within the UN system to persons affected by those sanctions ${ }^{55}$. Lastly, it should be recalled that not only has a similar stance been adopted by some domestic courts ${ }^{56}$, but also that no significant contrasting action has been so far taken at the international level. By this, I will not deny, of course, that this tendency has developed so far with specific regard to the question of the SC targeted sanctions, nor will I advance the hypothesis that customary international law has developed to the point where a State may invoke its constitutional provisions concerning access to justice as a legal excuse for failure to perform conflicting international obligations.

Instead, it is quite clear to me that the recourse had by the Constitutional Court to this right may be traced back to the aforementioned tendency. Despite the fact that its judgment relates to the different issue of state immunity, there is no doubt that, by invoking the right to judicial protection in the face of the consequences stemming from such a regime, the Court aimed to assign to the former a role which appears to be analogous to the one played by it in the case law in respect of the SC targeted sanctions. In all these cases, access to justice, so as provided for by the legal orders at stake, tends actually to be considered as prevailing over conflicting international obligations, insofar as respect for these obligations would entail a denial of judicial

\footnotetext{
${ }^{55}$ Kadi (n 53) para 133; Al-Dulimi (n 54) para 134; for a detailed critical assessment, see M Arcari, 'Forgetting Article 103 of the UN Charter? Some Perplexities on "Equivalent Protection” after Al-Dulimi’ (2014) QIL-Questions Intl L Zoom-in 6, para 3.

${ }^{56}$ For ex: High Court Of Justice, Queen's Bench Division, Administrative Court, Hay c H.M. Treasury and Secretary of State for Foreign and Commonwealth Affairs, Case no CO/1200/2009 (10 July 2009); adde: Supreme Court of the United Kingdom, Her Majesty's Treasury (Respondent) v Mohammed Jabar Ahmed and others (FC) (Appellants); Her Majesty's Treasury (Respondent) v Mohammed al-Ghabra (FC) (Appellant); R (on the application of Hani El Sayed Sabaei Youssef) (Respondent) v Her Majesty's Treasury (Appellant), Case no [2010] UKSC 2 (27 January 2010); Federal Court of Canada, Abousfian Abdelrazik v The Minister of Foreign Affairs and The Attorney General of Canada (4 June 2009); see M Marchegiani, 'Le principe de la protection équivalente dans l'articulation des rapports entre ordre juridique des NU et CEDH après l'arrêt Al-Dulimi' (2014) QIL-Questions Intl L Zoom-in 6.
} 
protection of the fundamental human rights come to the fore. Within these limits, one may therefore wonder if the judgment at issue is also to be deemed a significant contribution to the progressive development of a regional customary rule, according to which European States may invoke constitutional provisions on access to justice, as a circumstance capable of precluding the wrongfulness of their failure to comply with conflicting international legal duties.

* This article was originally published in QIL - Questions of International Law, available at http://www.qil-qdi.org/.

Pasquale de Sena é professor de Direito Internacional e Direitos Humanos na Università Cattolica del Sacro Cuore (Milão - Itália).

E-mail: pasquale.desena@unicatt.it

Endereço profissional: Università Cattolica del Sacro Cuore, Largo A. Gemelli n. 1, Milano, Italia - 20123. 
